\title{
Ironies of Christian Presence in Southern Africa
}

\author{
Sibusiso Masondo \\ masondosi@ukzn.ac.za
}

'Indeed, it can be argued that the modern missionary movement from the West, along with other developments within Western Europe, played a significant role in bringing about the crumbling of Western Christendom, though this outcome may not have been intended' (Bediako 2000:316).

\begin{abstract}
Christianity was meant to be one of the most potent weapons in the armory of European Imperialism. John Philip characterized mission stations as the cheapest and the best military posts any wise government can employ to defend its frontiers against the predatory incursions of savage tribes (Villa-Vicencio 1988:44). Christianity was meant to colonize the conscience and consciousness of the colonized in ways that would make them lose their indigenousness. It was meant to 'make' or 'create' the colonized in the image of the colonizer. The irony of this situation is that, among other things, it created conditions for the desire among the colonized to be free; it contributed to the emergence of African Nationalism through notions like 'brotherhood' and 'oneness in Christ'. It became a serious problem for the Christianized and educated natives to find themselves excluded from the Christian family on the basis of their ethnicity. David Chidester's work on the history of religion in Southern Africa provides a very useful background for exploring the ironies of Christian presence in Southern Africa. Lamin Sanneh's observation about the role played by indigenous religions to enable both Islam and Christianity to take root is invoked in this context. Christianity became part of the complex that laid the foundations for African nationalism and the pan-Africanist ideology. It provided a platform in mission stations and mission schools for the forging of
\end{abstract}


a unified African identity. Education, given to Africans to become 'civilized' and alienated from their African compatriots, instead, helped in creating a consciousness for liberation among the oppressed Africans.

Keywords: missionaries, Christianity, African Traditional Religion

\section{Introduction}

The history of religion in Africa did not start with the advent of Christianity or the arrival of European settlers and missionaries (Sindima 1990:206). When the Europeans arrived in Southern Africa, Africans had been practicing their own religion from time immemorial. Religion had sustained Africans and their way of life, and they were able to build communities and political systems. The history of Christianity in sub-Saharan Africa is full of ironies. First, the primary task of the missionaries was to introduce Christianity to the 'dark' continent and convert the 'savages'. Such an endeavor was accompanied by colonial desires to 'civilize' the natives. In other words, the aim was to introduce Western European forms of civility and enforce it as superior to African notions of being in the world. Christianity was accompanied by education and health - the African was perceived as a blank slate on which Europeans could write and reproduce themselves. In this endeavor, 'African values of industry, sanctity of life, respect of persons, and community were all undermined' (Sindima 1990:192). Second, the only way Christianity was able to take root in Africa was through the infrastructure of indigenous religions. Such was accomplished through the translation of some of the Christian practices and concepts into the local idiom. The role of lay African church workers is often under-emphasized. Hlonipha Mokoena's work on the relationship between Magema Fuze and Bishop Colenso is a good example of how lay African workers participated in the processes of not only spreading Christianity but defining it as well. Third, Christianity was converted into an indigenous religion through the efforts of Africans within the mainline churches and the emergence of African Indigenous Churches (AICs). Fourth, Christian resources were used to fight colonialism and oppression. It provided both space and intellectual resources for the conceptualization of African nationalism and other political movements that sought liberation from colonialism. Charles 
Villa-Vicencio (1988:42-43) states that 'the church socially transformed the proselytized, in turn, although to a lesser extent, carried their values into the church'. The non-conformist missionaries were Protestants, whose faith emanated from rebelling against the Roman Catholic Church dogma and orthodoxy. However, there was failure to appreciate African discontent with the established church and the eventual formation of the AICs. Infantilization of Africans by missionaries and Europeans in general, was one of the central reasons for the early wave of African Christian independency.

\section{European perceptions of Africa}

Jan Platvoet (1996) points out that traders, travelers, slavers, missionaries, military men, colonials, and administrators objectified and undermined Africa and Africans. For Villa-Vicencio (1988:44), 'the Gospel of the missionaries was linked to the ideology of British colonialism'. All these people developed their views on Africa based on their European worldview. Their worldview determined how they analyzed what they saw. Given their backgrounds, they were unable to empathize with the African. Their mind was flooded with images of difference - difference in this case was seen as inferior. Ideologies of otherness were developed by the use of Judeo-Christian templates as a standard to understand non-Western religions. For Horton (1984:403), 'Judaeo-Christian religious discourse...celebrates the primacy and centrality of the supreme being as against all lesser spiritual agencies'. This became clear in the terminology that became part of the colonial discourse, i.e., nonEuropeans, non-Whites, etc.

David Chidester (1996) recorded responses of missionaries at different periods to Africans as people and their social systems. In fact, 'early Western Studies of world religions divided the history of religious practices into three evolutionary phases' (Greene 1996:122). On initial contact, Africans were said to be a people without any religion - true or false. The implications of such a determination were that Africans were not humans and could therefore be enslaved and deprived of human dignity. Later on, the presence of religion was acknowledged but it was deemed inferior. Africans were said to be in the early stages of evolution or Fetishism, meaning that they were at the point where Western religions were hundreds of years ago. In other words, they did not 


\section{Sibusiso Masondo}

belong to the modern era - this was a creation of the superhuman, the human, and subhuman categories. There are serious implications for saying that people do not belong to an era or are inferior. HF Verwoerd applied this principle in his justification for Apartheid where Blacks were said to be only good for providing labor and nothing more. In fact, the National Party 'stood for the "Christian guardianship" of the European race over the non-white races' (Venter 1999:422).

Western biases created the following images of Africans and their beliefs, called primitive superstition: They are rife with bloody sacrifices, human sacrifices, evil witchcraft, black witchcraft, voodoo, and cannibalism (Owomoyela 1994; Villa-Vicencio 1988). Such Western biases were supported by scholars like Georg Hegel. According to Kuykendall (1993), Hegel characterizes Africans as unhistorical and having contributed nothing to human civilization. Their spirit was undeveloped and still involved in the conditions of mere nature. In other words, Africans had not evolved or made any progress. Africans were devoid of morality, religion, and political constitution, therefore providing a good justification for subjugating and enslaving them. The African was a 'natural man in his completely wild and untamed state' (Kuykendall 1993:580). He was still influenced by nature and responded to its rhythms. Hegel's work clearly disrespects Africa's contribution to civilization and grossly misinterprets Africa's place in world history. In fact, 'Hegel's philosophy of history is a philosophical treatise that disrespects Africa's contribution to civilisation' (Kuykendall 1993:580).

\section{Indigenous religion and religious pluralism}

African Traditional Religion (ATR) did not pass judgment on other religions. It recognized the fact that they were telling part of the story of human interaction with the universe and Divinity. Ghanaian scholar Kofi Opoku invokes an Akan proverb that 'wisdom is like a baobab tree, a single man's hand cannot embrace it' (Opoku 1993:67), in his attempt to demonstrate the openness of the African worldview to other interpretations of reality. As a result, Africans did not mind borrowing aspects of Christianity in their journey through life. Indigenous religion played a crucial role in molding Islam and Christianity in West Africa - this can also be applied to other parts of the 
continent. The ATR provided an intellectual and conceptual infrastructure for both Islam and Christianity to make inroads among Africans, as the latter were able to understand and identify with religious concepts from the two religions from the perspective of their understanding of indigenous concepts. Islam and Christianity would have found it very difficult to operate in the absence of the indigenous infrastructure. The two religions found aspects that they approved and disproved in the ATR. In developing her thesis on the Supreme Being in Africa, Sandra Greene (1996) has noted that there was much movement and interaction between various groups in Africa. These interactions were for purposes of trade, establishment of strategic alliances, as well as wars. Through these interactions, information was shared.

Kalu (2013:17) makes a very good point, arguing that ' $[\mathrm{t}]$ he irony in nationalist historiography is that while condemning missionaries, the authors fail to see that their own people, the Africans, were the real agents who spread Christianity'. One can boldly say that African converts and church workers practiced comparative religion. They were able to see aspects that were similar and made sense of them in their context. These church workers interpreted Christianity in ways that made sense to indigenous people. Deborah Gaitskell (2000) significantly captures another group of African church workers - the Biblewomen - who promoted Christianity in people's homes. Colenso also believed in taking the Gospel to where people lived. In fact, he 'became infamous and was eventually excommunicated' (Mokoena 2008:313) for confessing that his interactions with converts convinced him that the Bible should not be taken as the literal truth.

\section{Christian Independency}

According to Lamin Sanneh (1993), a question that occupied people toward the end of the $19^{\text {th }}$ century in West Africa, was not whether Christianity would survive as a religion, but what form it would take going forward. At this point, Christianity had been firmly planted on African soil. However, it must be pointed out that this was made possible by a partnership between European missionaries and their African converts. Increasingly, Africans were given more responsibilities in the affairs of the church. African evangelists traveled from village to village promoting Christianity. There was always reluctance to 


\section{Sibusiso Masondo}

ordain African ministers. Oosthuizen (1990:103) makes this point very well, saying: 'Only in the early 1960s did John Xaba's Anglican Church, with its socalled liberal stance, induct the first African Bishop, the Venerable Alpheus Zulu. The reluctance to accept African leadership at the highest level in this church was due to racial prejudice'.

There were also economic and political forces that undermined traditional institutions and ideas. Modern education introduced aspects that contradicted local knowledge. Edward Berman (1974:527) elaborates: 'Missionaries, as agents of European churches, constructed schools because education was deemed indispensable to the main purpose of the Christian denominations - the spread of the gospel of Jesus Christ. Missionaries recognized that the school was, in the words of one commentator, "the nursery of the infant Church"'. During this critical time in history, missionaries and African religious practitioners engaged in what Jean and John Comaroff (1991) call a 'conversation'. It was a negotiation between two worldviews or systems of thought. Missionaries challenged indigenous ideas on social organization and food production. Some missionaries got involved in debates over the effectiveness of indigenous ideas on social organization and food production. Others involved themselves in debates over the effectiveness of indigenous rainmaking rituals to the extent that they became rainmakers. Rev. Broadbent told the Tswana rainmaker that only God can make rain. The rainmaker failed to make rain a few times and Broadbent went on to pray. After the prayer the rain came down and the place was flooded. He interpreted those events as indicating that God was not pleased with the way the Tswana people were conducting themselves. Local people began to see him as a rainmaker. Broadbent was identified according to the results he achieved in the rainmaking contest. In the eyes of the local population he was a sacred specialist with mystical powers, the ability to make rain being one of those powers. Furthermore, Norman Etherington points out that in Natal some women sought refuge in mission stations in order to avoid their calling as diviners, whereas missionaries 'advertised themselves as agents of countervailing spiritual power' (Etherington 1976:597).

Missionaries used interesting agricultural metaphors to demonstrate what their mission was doing. In describing this process, Robert Moffat of the London Mission Society stated that missionaries ought to put their hand to the plough in preparing the stony African ground for a 'rich harvest of souls' (Comaroff 1991:12). Agriculture would cultivate the worker as the worker 
cultivated the land. In fact, the production of new crops and a new kind of selfhood went together in the evangelical imagination. The African social organization posed a problem for this vision. African gender relations did not align with those of the missionary establishment. The two patriarchal systems had different views on the roles and responsibilities of women. In the African context, the domain of women extended from the domestic domain to food production, as they were responsible for agriculture, food production, and gathering. According to Sean Hanretta (1998:391), 'women were located at the very source of power within that society; agricultural production'. Men were responsible for hunting of game and animal husbandry. In the missionary imagination, informed and influenced by the Victorian era ideals, a woman was supposed to have lordship over the domestic space, creating a homely environment, raise children, and cook for her husband as well as all other domestic chores. The man was supposed to use his physical strength in agricultural production and generally providing food for his family. The idea of a man as a provider for his family was firmly established.

The introduction of animals drawing a plough as an important agricultural tool posed a paradox for Africans as it traversed previously separated male and female domains. There were prospects for higher yields and surplus, as men became interested in agriculture. First, women were not allowed to handle animals. Second, surplus products were sold at the market. Here one can already see signs of the disruption of the traditional social organization. Women had some influence in this area, but it was taken away from them. Terence Ranger (2003) demonstrates that African women were responsible for agricultural production and the development of many fertility cults. Isabel Mukonyora (1999) is of the view that the idea of Mwari presented in most studies on Zimbabwean religion, is from a male perspective. In this perspective, Mwari is a territorial divinity who defends it against invaders (a prerogative of males). Her view is that when Mwari is seen as a fertility god, one is able to see the contribution of women in conception. Mwari's praise name, Zvivaguru (great pool), indicates that she has to do with fertility. A pool is a fountain of life, in the same way as a woman's womb.

Women were in touch with nature on an ongoing basis (collecting vegetables, wood, and water). Rivers and pools are places where women met and taught each other on sexuality and performed initiation rites. 
Put another way, women in traditional Shona culture fulfilled roles that can explain the development of earth-centred myths, folk stories, and associated religious beliefs...but when we consider the daily activities of women on the land in growing crops, looking for water to drink, fetching firewood, spending time at the pools and rivers carrying out initiation rites, etc., it is clear that women had time to develop a more intimate relationship with nature than men (Mukonyora 1999:281).

It was this strength that women possessed that was used against them. They were dismissed on the fact that being closer to nature was making them inferior to men.

During the colonial era, white control began to be seen as indispensable to the effective management of the church. Africans were removed from positions of influence. This act did not set off an immediate reaction from the African population. Literature on the encounters between missionaries and Africans suggest that for the majority of missionaries, Christian conversation required disowning African religious and cultural practices and then accepting Christianity together with Western cultural practices. Beidelman (1982) was of the view that missionaries were an important part of the colonial project whose aim was not simply to dominate politically, but culturally as well. Furthermore,

Christian missions represent the most naïve and ethnocentric, and therefore the most thorough-going, facet of colonial life... Missionaries invariably aimed at overall changes in the beliefs and actions of naïve peoples, at colonization of heart and mind as well as body. Pursuing this sustained policy of change, missionaries demonstrated a more radical and morally intense commitment to rule than political administrators or businessmen (Beidelman 1982:5).

Missionaries cast African culture, tradition, and customs in a negative light, according to Simensen (1987). They spent huge amounts of time in their teachings and sermons defining sin in narrow personal terms, thus individualizing sin and salvation. Such definitions of sin ignored the structural and systemic issues that caused harm on people. As a result, '[m]ost aspects of Zulu culture came under the definition of sin, based not only on Christian but also on specific European cultural criteria. This naturally kept the cost of 
religious change high in terms of conflict with family and local society' (Simensen 1987:96).

Among the AmaXhosa in the second half of the $19^{\text {th }}$ century, missionaries insisted that their members should have nothing to do with any of their traditional customs, otherwise they could face the possibility of being expelled. Mills (1995) points out that the missionary campaign against customs like circumcision (male initiation), lobola (bride-price), intonjane (a girl's puberty rites), and polygamy promoted 'deception, breaches of discipline, disobedience of children and hypocrisy'. For example,

Revd J.J.R. Jolobe said that he and his brothers had all, under the guise of visiting relatives, arranged to be circumcised and had been successful in hiding the fact that their father, Revd James Jolobe, did not learn about it until years later. Mr Zizi Mazwai said that he and his brothers had also quietly arranged operations at hospitals, in spite of the Revd Ambrose Mazwai's denunciation of the custom (Mills 1995:165).

Why did these young men take a risk to defy their parents and perform such procedures? It had something to do with societal pressure and a desire to be accepted. It says something about the value placed on such practices by their practitioners. There is a widely held notion among the AmaXhosa that any male who had not been through initiation is still regarded as a boy. Such males are touted and teased especially at gatherings and ceremonies.

There were serious moral problems faced by African converts as a result of the banning of puberty rituals in Natal. Deborah Gaitskell (1982) pointed out that the formation of the mother's prayer group, isililo (wailing), in the Congregational Church in Natal, was a direct consequence of the upsurge of teenage pregnancies among mainly Christian children at the turn of the $20^{\text {th }}$ century. She attributed this to the discontinuation of puberty rituals without any replacement. During these rituals, girls were taught about intricacies of sex and proper ways of behavior. Missionaries expected girls' mothers to take over the role of sex educator, while such expectations were in direct contrast to African beliefs and customs. Traditionally, sex education was the responsibility of adults other than the parents of the said children. During the pre-Christian era, parents were not responsible for this type of education for their children. Sindima (1990:193) makes a very good argument, stating that 
'to abolish ritual practice was to do away with critical and transforming moments in personal and communal life'.

Simensen (1987) recalls another example of dishonesty by a man called Isaac, as a result of an anti-African culture missionary policy. Isaac came to the mission station where he acquired business skills and became a successful businessman. He was baptized and confirmed into the church. After acquiring some wealth, he became successful and decided to take a second wife.

One tempting opportunity to convert profit into status based on the criteria of Zulu society was to take several wives. At his cattle farm Isaac entered into a relationship with a girl who was to become his wife number two. To deceive Oftebro and the congregation he brought along this girl to Eshowe and registered her as a school pupil. He declared himself free from sin, and joined in Holy Communion as usual. When the truth was brought home to Oftebro through rumours and reports from other Christians, Isaac defended himself by pointing to the polygamous practice of Abraham and Isaac in the Old Testament (Simensen 1987:98).

Such an argument is a direct consequence of translation of the Bible into indigenous languages coupled with mission schooling. Missionary Jon Kirby (1994) reports that missionaries in Ghana did not want to understand African religion institutions and culture. A veteran missionary told him not to bother learning native languages because he had to continue speaking English in order to help Africans improve their command of English. Christianity, as presented by the missionaries, carried with it a baggage of Western culture, practices and values, and these were presented to Africans as part of the furniture of Christianity. In other words, Africans had to be European before they became Christian - a practice reminiscent of the demands made by Judaizers in the early church, that all Gentiles must be circumcised like the Jews (Ac 15:1-29). 


\section{Christianity and translation}

In his provocative book Whose religion is Christianity?, Lamin Sanneh (2003) points out that, unlike Islam, Christianity does not have a language of revelation, and its sacred texts are not in the language of the founder. In fact, from its very foundation it has been translated into various languages: 'The fact of Christianity being a translated, and translating, religion places God at the center of the universe of cultures, implying free coequality among cultures and a necessary relativizing of languages vis-à-vis the truth of God' (Sanneh 2003:105). The translation of Christianity in Africa was in two processes that were not mutually exclusive, that is, linguistic and cultural. African evangelists and church workers were largely responsible for translating the message of Christianity into the local idiom.

Christianity permitted the use of indigenous languages for both selfunderstanding and the appropriation of Christian religion. The use of local languages in the conception and promotion of Christianity undermined its foreign character. The translation of the Bible ushered in a fundamental religious revolution: The Bible as a religious resource became accessible to Africans in their own languages. Local concepts, idioms, and religious categories were used to understand and mediate the Christian message and experience. According to Sanneh (2003:99), 'Christians became pioneers of linguistic development with the creation of alphabets, orthographies, dictionaries, and grammars'. African rites and practices were converted into vehicles for the spread of Christianity - they were cleansed for the purpose of the use in the church, for example, initiation for baptism. There was mass participation in this process. The god of the ancestors was assimilated into Yahweh of ancient Israel, and God the Father of our Lord Jesus Christ. The power of the witches was compared to the power of Jesus: The concept of mystical powers possessed by the indigenous specialists was used to understand and make sense of the power of Jesus.

Some missionaries began to appreciate the depth and richness of African religion and culture. Hastings comments that not all missionaries supported the colonial project in its totality. There were those that he identified as rebels who did not follow the line of missionary societies on some issues. Among such missionaries he identifies Colenso and Livingstone as 'intellectual princes of the nineteenth century missionary movement [who] were both rogue elephants, too independent in mind for the movement to 


\section{Sibusiso Masondo}

contain them' (Hastings 1994:265). Colenso did not agree with the position of the church by forcing men in polygamous marriages to leave all their wives but the first one. He felt that such a move was not pastoral and would result in abandoned children. According to Kaplan (1986), Colenso advocated for such men to be accepted in the church and communion, but not to hold church office. Jones (2011:399) reminds us that Colenso 'did not promote polygamy, or think that it was an ideal, but argued for toleration of polygamy until an ideal could be reached'. Unfortunately, such views were only held by a minority, while the majority of missionaries continued to deny men in polygamous marriages membership in the Christian community. Kaplan (1986:168) also confirms that there was no unanimity at the 1888 Lambert conference on the non-baptism of polygamous men. Jones, furthermore, laments the absence of the voices of women in the debate on polygamy.

Translation was central to the revitalization of indigenous societies through the invocation of local paradigms. For Sanneh (cited in Gilmour 2007:1769), 'Missionary translation was instrumental in the emergence of indigenous resistance to colonialism. Local Christians acquired from the vernacular translations confidence in the indigenous course. While the colonial system represented a worldwide economic and military order, mission represented vindication for the vernacular'. Colonialism and Christianity intended to produce a particular type of African who was a mirror image of their colonial masters, but it had unintended consequences. The process of conversion involved what Norman Etherington (2002:436) called 'outward and visible signs'. African converts were given new names after baptism. Such names were of notable biblical figures and some prominent missionaries. The aim for such an exercise was to obliterate the previous identity. Jesse Mugambi (2003:53) argues, 'While mission schools instructed their African pupils and students to accept, obey, and copy their colonial masters, these learners at the same time acquired knowledge and skills which were to become essential tools in the nationalist struggles for self-determination'.

According to Sanneh (1996:123), 'Local Christians apprehended the significance of world events, and as such the purposes of God, through the familiar medium of mother tongues, with subject peoples able to respond to colonial events in light of vernacular self-understanding'. Furthermore, Kiernan (1990:13) observes that Africans 'responded to the missionary message through the filter of their own culture'. The translation of the Bible had some unintended consequences. Indigenous filters for understanding the 
gospel were developed. Some aspects of African culture rejected by missionaries were justified as locals had access to the Holy Scriptures in their mother tongues. In most cases, they found in the Bible, especially the Old Testament, communities that were similar to theirs. It also became the major catalyst behind the formation of the AICs. According to Gosnell Yorke (2004:154), scholars like Sanneh and Bediako 'have shown that there is a clear correlation between the translation of the Bible into indigenous African languages and the cultural renaissance that we see at work in the rapidly proliferating African Independent, Instituted or Indigenous Churches'.

Ethiopian churches are the pioneers of the AIC movement in South Africa. These churches were founded for and by urban educated blacks who were increasingly being sidelined by the white missionary establishment. Their heydays were between 1880 and the 1920s. The breakaway from the mission churches was meant to ensure African control on ecclesial matters. Ethiopian churches in the late $19^{\text {th }}$ century were founded as a protest against (a) white domination, (b) the ceiling imposed by white domination of the aspirations of African church workers, (c) the ease with which Africans were expelled from the church, especially for plural marriages, and (d) growing segregation between black and white congregations. A very clear disjuncture between the concept of oneness in Christ and the practice of a mission-controlled church became a major concern of this group.

Ethiopian churches rejected white control and domination. However, they accepted the core of missionary teachings, that is (a) the retention of the doctrines and the practices of the mission, and (b) the promotion of values like character-building, hard-working, discipline, capital accumulation, morality, education, and industry. This is an indicator that the problem was not ecclesiastical but political. Ali Mazrui's insights are helpful in this attempt to analyze the symbol of Ethiopia as a Pan-African symbol for all Africans. He said that 'Pan-Africanism is based on a positive false memory - that Africa was divided by colonialism and was previously one' (Mazrui 2000:90). In fact, 'missionary teaching...played an important part in encouraging the growth of nationalism among the kholwa. The truly revolutionary idea that Africans were all one people regardless of ethnic origin was preached vigorously in southeast Africa' (Etherington 1976:604). The idea of brotherhood in Christ transcended ethnic differences especially at mission stations, and as such, it became one of the factors that enabled the formation of the African National Congress in 1912. 
According to Chidester, various white governments distrusted the Ethiopian movement. In fact, '[i]n spite of its basically middle-class morals, values and aspirations, however, the Ethiopian movement was perceived by government as a threat simply by virtue of its independence from white control' (Chidester 1992:119). Various commissions were set up to investigate the activities of these churches, but they found no evidence to support the claim that they posed a danger to the state. The white establishment saw these churches as a threat. Such initiatives by Africans were said to represent 'a Christian heresy, a political threat, and... a foolish desire to get rid of the white man's control' (Chidester 1992:119).

One of the reasons for the emergence of the Ethiopian spirit was the perception that the missionaries were involved in the colonial schemes that subjugated Africans. Simensen (1987) points out that some Norwegian missionaries in Natal identified African independence as an obstacle to Christianization. They joined their English colleagues in supporting efforts to undermine Zulu independence using force. Sindima (1990:191) indicates that in other parts of Africa missionaries instigated and even participated in colonizing areas.

\section{Pentecostalism}

The bulk of literature on Pentecostalism insists that the initial founders of this movement were foreign missionaries. However, the phenomenon was adapted to local conditions by some of the initial converts to address African needs. Allan Anderson (1992) points out that Azusa Street became a focal point of Pentecostalism and it produced missionaries who went out and spread the Pentecostal messages in fifty countries in two years. Soon after the Azusa Street Revival of 1906, a large number of missionaries went to different parts of the world, including the African continent. People like John Lake, his wife, and three other friends came to South Africa in 1908 where he founded the Apostolic Faith Mission (Nel 2015:149).

Pentecostalism started as an interdenominational and multiracial movement, and it appealed to black and white people in South Africa. Marius Nel (2015:156) reports that John Lake reprimanded those in his audience who were against him embracing Elias Letwaba. He did not take kindly to the overt 
racism that was displayed by some white members of the congregation in Johannesburg during his first sermon in South Africa. In fact, '[t]he broad character African Pentecostalism is very ecumenical, against ethnicity or tribalism while effecting a new unity in Christ among Christians of various hues' (Kalu 2002:129). However, racism and discrimination against Blacks has been the feature of South African Pentecostalism since its inception. Anderson (2000) records a number of incidents where white people sought to sideline black people from the work of the ministry. After the formation of the Apostolic Faith Mission (AFM) in 1908, its white dominated council passed a declaration that during baptismal services, natives had to be baptized after white people. As early as 1910 , black and white people were holding separate annual conferences. In fact, 'churches were separated along racial lines and black Pentecostal churches were intentionally disempowered' (Nel 2015:158). The white AFM council supported discriminatory and racist ideas advocated by the National Party, and that became official government policy in 1948.

Pentecostalism has evolved into a very powerful force across the African continent. The emergence of charismatic churches led by powerful individuals who claim to have divine powers to heal, exorcise evil spirits, help people to become rich, and predict the future, became a prominent feature of Christianity in Africa. Paul Gifford (2004), in his article titled Persistence and change in contemporary African religion, argues that charismatic churches present an ideology that is consistent with a traditional African worldview that mission churches had disapproved. In the traditional worldview there is no separation between the physical and the spiritual realm. The spirit, according to Mbiti (1969), infuses all aspects of life. In other words, anything happening in the physical realm is explained in terms of what is happening in the realm of the spirit. In fact, "natural causality is to be discerned primarily in the spiritual realm' (Gifford 2004:172). Gifford makes reference to the Winner's Chapel in Nigeria and other Charismatic churches where the 'success' and 'prosperity' in the 'here' and 'now' are prominent messages. The notion 'success in the here and now' is consistent with the ATR's this-worldly orientation. The ideology of success here and now is re-enforced through testimonies. Individual members testify to the group about their 'successes', because of their attachment to the group and following the teachings of the leader. Some of the testimonies are used on flyers and other media to promote the group. Furthermore, Gifford (2004:173) suggests that 'Africa's new Christianity promises the this-worldly blessings of traditional religion (as 
expected, heaven and hell are seldom mentioned)...herein lies the secret appeal'. This is very ironic as the major aspects that were rejected by early missionaries are the ones that are used to draw people into these new forms of Christianity in Africa. The irony is aptly put by Richard Gray (1982:64) that

African Christianity is not the result primarily of a massive campaign of brain-washing by foreign missionaries. Whatever the missionaries may have thought, Africa was no tabula rasa. Aspects of Christianity were eagerly accepted and transformed by Africans because this faith was seen to meet not merely the exigencies of modernization but also at least some of the long-standing spiritual needs and demands of African societies. Christianity in Africa was never synonymous with the missionaries' understanding of the faith; the encounter with Africa involved a process of interaction in which Africa's distinctive characteristics and contributions have become ever increasingly prominent.

\section{African theology}

African theology emerged as a critique of traditional ways in which theology was done, especially with regard to the place and role of Africa in the narrative of salvation. It sought to place Africa at the center of the theological enterprise. According to Justin Ukpong, African theology is the 'conscious engagement of European Christian thinking and African religious thought in serious dialogue for the purpose of integrating Christianity into the life and culture of African people' (Ukpong 1984:501). For Desmond Tutu it 'has given a lie to the belief that worthwhile religion in Africa had to wait the advent of the white man...African Theology has done a wonderful service in rehabilitating the African religious consciousness' (Tutu 1987:53). The negative portrayal of Africa, African people, and their religious heritage in the writings of mainly European commentators prompted African scholars to respond. In such studies, Africa was presented as backward and having had no contribution to world history.

Winds of change blew across Africa in the 1950s and 1960s with a number of African countries getting their independence from colonial 
governments. The idea of Pan-Africanism and nationalist ideologies had some influence on the development of African theology. Post-colonial governments put pressure on the church to Africanize. The post-colonial leadership wanted to demonstrate that they were different and had respect for African heritage. The church had to respond to socio-political changes, becoming relevant.

John Mbiti is of the view that religion among Africans has permeated into all departments of life so fully that there is no easy or possible way to isolate it. Both Christianity and Islam flow into the overall history of African religion. For him, all religions except Christianity constitute in the highest ideals, 'a praeparatio evangelica' (cf. Bediako 1989:60; Kalu 2002:113). In other words, African indigenous religions were only useful as a stepping stone to a more superior form of religious expression that came with Christianity. For Mbiti, Christianity provided an African with freedom, maturity, selfhood, and fulfilment. Almost a century before Edward Blyden, he already stated that Christianity is the highest form of religious expression. In other words, Africans must acquire it in order to be progressive and lead a fulfilled life. The assumption is that indigenous religions were not looking ahead and could not help Africans to advance and participate meaningfully among the family of nations in the world. Many of the kholwa leaders, like John Dube at the turn of the $20^{\text {th }}$ century in South Africa, were of the view that Christianity and education were the only ways to advance development in Africa.

Pre-Christian reflections about God were contained in wisdom sayings, myths, ritual pronouncements, and prayers. There are striking resemblances to biblical ideas, especially the Old Testament. Leaders like Isaiah Shembe, at the beginning of the $20^{\text {th }}$ century, were quick to establish the resemblances between people in biblical stories and their own communities. Mbiti, having observed the workings of the ATR and its methods of generating ideas, concluded that adherents of the ATR will almost be negligible by 2000 $\mathrm{CE}$ and will bequeath the riches of African religiosity to Christianity. Christianity was said to supersede the ATR by introducing dimensions they lack - stuff not opposed to traditional religiosity.

The Bible became a very important source for the justification of resistance against racial discrimination and other injustices meted out to African people. There was a general appeal to Christian teachings and values to support the liberation project. Christian nationalist leaders like Chief Albert Luthuli (1962) drew heavily on the Bible to justify his actions. The title of his book Let my people go, drew its inspiration from the book of Exodus where 
Moses had discussions with the Pharaoh about the liberation of the Hebrews. The liberation motif of the book of Exodus inspired him to put more effort in the struggle for the liberation of African people in South Africa.

\section{Conclusion}

The aims of those who brought Christianity to Southern Africa were for it to take root and for indigenous people to be re-formed in their image. According to Ranger (1991), Protestant missionaries were committed to Christianity, commerce, and civilization, and they saw African religion as anti-progress and a force that they needed to fight and defeat. The main aim of colonization and evangelization was to alter the consciousness of African converts. Jean and John Comaroff (1991:268) perceptively point out that 'any attempt to understand the southern Tswana past and present keeps being drawn back to the colonization of their consciousness and their consciousness of colonization'.

Everything around African converts reflected alien symbols. African converts were removed from the community and placed in mission stations, where missionaries attempted to alter their worldview to Christianity or Western ways or sekgoa. The term for an African convert, ikholwa, has evolved from something that is despised, to something acceptable and even desirable. Early African converts were regarded as traitors (amambuka) for having deserted their people and their communities, especially their ancestors. The attitude of early converts was that Christianity and Western civilization were bringing light to a dark continent. The desire of most African converts was to be assimilated into the white colonial community and economy as equals. The refusal of the colonial establishment to accord these educated African Christians equality with whites made them realize that they needed other black people to fight colonial injustices. Christianity gave space for the creation of a consciousness for liberation among Africans. Such a consciousness was manifested in African nationalism that inspired a number of liberation movements across the continent, including the AICs. These churches were expressions of the desire of Africans for freedom and human dignity. However, the most important statement that was made through the formation of these churches is that Christianity was converted from an alien religion into an 
indigenous one. It is no longer alien because it is now expressed and experienced through the local idiom. The most interesting irony is that a religion that sought to transform an African worldview was also transformed to serve the interests of an African worldview. It is indeed ironic that for Christianity to survive and thrive, it needed the very religion and culture that it sought to destroy.

\section{References}

Anderson, A. 1992. Bazalwane: African Pentecostals in South Africa. Pretoria: UNISA Press.

Anderson, A. 2000. Zion and Pentecost: The spirituality and experience of Pentecostal and Zionist/Apostolic churches in South Africa. Pretoria: UNISA Press.

Bediako, K. 1989. The roots of African theology. International Bulletin of Missionary Research 13, 2: 58-65.

Bediako, K. 2000. Christianity on the threshold of the third millennium: The religious dimension. African Affairs 99, 395: 303-323.

Beidelman, T.O. 1982. Colonial evangelism: A socio-historical study of an East African mission at grassroots. Bloomington: Indiana University Press.

Berman, E.H. 1974. African responses to Christian mission education. African Studies Review 17, 3: 527-540.

Chidester, D. 1992. Religions of South Africa. London: Routledge.

Chidester, D. 1996. Savage systems: Colonialism and comparative religion in Southern Africa. Charlottesville, London: University Press of Virginia.

Comaroff, J. 1991. Missionaries and mechanical clocks: An essay on religion and history in South Africa. The Journal of Religion 71, 1: 1-17.

Comaroff, J. \& J.L. Comaroff. 1991. Of revolution: Christianity, colonialism, and consciousness in South Africa. Chicago, London: Chicago Press Corporation.

Etherington, N. 1976. Mission station melting pots as a factor in the rise of South African black nationalism. The International Journal of African Historical Studies 9, 4: 592-605. 
Etherington, N. 2002. Outward and visible signs of conversion in nineteenthcentury KwaZulu-Natal. Journal of Religion in Africa 32, 4: 422-439.

Gaitskell, D. 1982. 'Wailing for puberty': Prayer unions, African mothers and adolescent daughters, 1912-1940. In Marks, S. \& R. Rathbone (eds.): Industrialisation and social change in South Africa: African class formation, culture and consciousness, 1870-1930. Essex, New York: Longman.

Gaitskell, D. 2000. Hot meetings and hard kraals: African Biblewomen in Transvaal Methodism, 1924-60. Journal of Religion in Africa 30, 3: 277 309.

Gifford, P. 2004. Persistence and change in contemporary African religion. Social Compass 51, 2: 169-176.

Gilmour, R. 2007. Missionaries, colonialism and language in nineteenthcentury South Africa. History Compass 5, 6: 1761-1777.

Gray, R. 1982. Christianity, colonialism, and communications in Sub-Saharan Africa. Journal of Black Studies 13, 1: 59-72.

Greene, S.E. 1996. Religion, history and the supreme gods of Africa: A contribution to the debate. Journal of Religion in Africa 26, 2: 122-138.

Hanretta, S. 1998. Women, marginality and the Zulu state: Women's institutions and power in the early nineteenth century. The Journal of African History 39, 3: 389-415.

Hastings, A. 1994. The church in Africa, 1450-1950. Oxford: Clarendon Press. Horton, R. 1984. Judaeo-Christian spectacles: Boon or bane to the study of African religions? (Les lunettes judéo-chrétiennes: aubaine ou fléau pour l'étude des religions africaines?). Cahiers d'Études Africaines 24, 96: 391-436.

Jones, T.W. 2011. The missionaries' position: Polygamy and divorce in the Anglican communion, 1888-1988. Journal of Religious History 35, 3: 393-408. DOI: 10.1111/j.1467-9809.2011.01077.x

Kalu, O.U. 2002. Preserving a worldview: Pentecostalism in the African maps of the universe. PNEUMA: The Journal of the Society for Pentecostal Studies 24, 2: 110-137.

Kalu, O.U. 2013. Introduction: The shape and flow of African church historiography. Available at: https://repository.up.ac.za/bitstream/ handle/2263/21579/002 chapter1 p001-023.pdf?sequence=3. (Accessed on 1 June 2018.) 
Kaplan, S. 1986. The Africanization of missionary Christianity: History and typology. Journal of Religion in Africa 16, 3: 166-186.

Kiernan, J. 1990. African and Christian: From opposition to mutual accommodation. In Prozesky, M. (ed.): Christianity in South Africa. Bergvlei: Southern Book Publishers.

Kirby, J.P. 1994. Culture change and religious conversion in West Africa. In Blakely, W.E., A. van Beek \& D.L. Thomson (eds.): Religion in Africa: Experience and expression. London, Portsmouth: James Currey, Heinemann.

Kuykendall, R. 1993. Hegel and Africa: An evaluation of the treatment of Africa in the philosophy of history. Journal of Black Studies 23, 4: 571581.

Luthuli, A.J. 1962. Let my people go. New York: McGraw-Hill Education.

Mazrui, A.A. 2000. Cultural amnesia, cultural nostalgia and false memory: Africa's identity crisis revisited. African Philosophy 13, 2: 87-98.

Mbiti, J.S. 1969. African religions and philosophy. London: Heinemann.

Mills, W.G. 1995. Missionaries, Xhosa clergy and the suppression of customs. In Bredekamp, H. \& R.J. Ross (eds.): Missions and Christianity in South African history. Johannesburg: Witwatersrand University Press.

Mokoena, H. 2008. The Queen's bishop: A convert's memoir of John W. Colenso. Journal of Religion in Africa 38, 3: 312-342.

Mukonyora, I. 1999. Women and ecology in Shona religion. Word \& World 19, 3: 276-284.

Mugambi, J.N.K. 2003. Christian theology and social construction. Nairobi: Action Publishers.

Oosthuizen, G.C. 1990. Christianity's impact on race relations in South Africa. In Prozesky, M. (ed.): Christianity in South Africa. Bergvlei: Southern Book Publishers.

Opoku, K.A. 1993. African traditional religion: An enduring heritage. In Olupona, J. \& S. Nyang (eds.): Religious plurality in Africa: Essays in honour of John S. Mbiti. New York, Berlin: Mouton De Gruyter.

Nel, M. 2015. Remembering and commemorating the theological legacy of John G. Lake in South Africa after a hundred years. Studia Historiae Ecclesiasticae 41, 3: 147-170.

Owomoyela, O.1994. With friends like these...A critique of persuasive antiAfricanisms in current African studies epistemology and methodology. African Studies Review 37, 3: 77-101. 
Platvoet, J. 1996. From object to subject: A history of the study of the religions of Africa. In Platvoet, J., J. Cox \& J. Olupona (eds.): The study of Religions in Africa: Past, present, and prospects. Cambridge: Roots and Branches.

Ranger, T. 1991. African traditional religion. In Clark, P. \& S. Sutherland (eds.): The world's religions: The study of religion, traditional and new religions. London: Routledge.

Ranger, T. 2003. Women and environment in African religion: The case of Zimbabwe. In Beinart, W. \& J. McGregor (eds.): Social history and African environments. Oxford: James Currey.

Ukpong, J.S. 1984. The emergence of African theologies. Theological Studies 45, 3: 501-536.

Sanneh, L.O. 1993. West African Christianity: The religious impact. Maryknoll: Orbis Books.

Sanneh, L.O. 1996. Piety and power: Muslims and Christians in West Africa. Maryknoll: Orbis Books.

Sanneh, L.O. 2003. Whose religion is Christianity? The gospel beyond the West. Grand Rapids: William Eerdmans.

Simensen, J. 1987. Religious change as a transaction: The Norwegian mission to Zululand, South Africa, 1850-1906. In Petersen, K.H. (ed.): Religion, development and African identity. Uppsala: Scandinavian Institute of African Studies.

Sindima, H. 1990. Liberalism and African culture. Journal of Black Studies 21, 2: 190-209.

Tutu, D. 1987. Black theology and African theology: Soulmates or antagonists. In Parratt, J. (ed.): A reader in African Christian theology. London: SPCK.

Venter, J.J. 1999. HF Verwoerd: Foundational aspects of his thought. Koers: Bulletin for Christian Scholarship 64, 4: 415-442.

Villa-Vicencio, C. 1988. Trapped in apartheid: A socio-theological history of the English-speaking churches. Maryknoll: Orbis Books.

Yorke, G. 2004. Bible translation in anglophone Africa and her diaspora: A postcolonialist agenda. Black Theology: An International Journal 2, 2: 153-166. 
Ironies of Christian Presence in Southern Africa

Sibusiso Masondo School of Religion, Philosophy \& Classics University of KwaZulu-Natal masondosi@ukzn.ac.za 